\title{
ČESKOSLOVENSKO A JEHO ROZPAD VE SVĚTLE FILOSOFICKÝCH TEORIÍ NACIONALISMU
}

Sto let od vzniku Československa a dvacet pět let od jeho rozpadu - dvě významná výročí roku 2018 - nám dávají prríležitost nejen připomenout si historické události, ale také je filosoficky interpretovat. Otázky suverenity, autonomie, sebeurčení národa nebo legitimity státní moci totiž vždy produkovaly teoretické kontroverze, jež se vzhledem ke komplikované historii Československa ve 20. století nemohly neprojevit také v praktické rovině. Ambicí tohoto textu je proto zachytit ty filosofické problémy, jejichž různá řešení měla př́ímý dopad na spolužití Čechů a Slováků. Hlavní důraz bude prrirozeně kladen na fenomén nacionalismu $\mathrm{v}$ jeho různých podobách. Podobně jako je možné psát o dějinách Československa $\mathrm{z}$ hlediska práva nebo ekonomie, je tedy tento text pokusem interpretovat naše dějiny ve světle určitých filosofických problémů.

Jako východisko může sloužit rozdílný vztah dvou dnes už samostatných národů ke vzniku společného státu. V České republice je 28. ř́jjen tradičně jedním z nejdůležitějších státních svátků. „Masarykovská“ tradice je neustále připomínána a velebena. Naproti tomu na Slovensku 28. ř́jen státním svátkem není, nikdy nebyl, a tradice „první republiky“ nehraje ve veřejném prostoru prakticky žádnou roli. Tato disparita je zvláštní a žádá si vysvětlení. Zrod první republiky měl totiž pro Slováky z hlediska jejich objektivní situace jednoznačně větší význam než pro Čechy. Před první světovou válkou byli Češi plně zformovaným národem s vlastním školstvím, bohatou kulturou a politickou reprezentací. Jejich přežití jako národa nebylo otázkou, kterou by bylo jakkoli potřeba řešit. Vznik Československa znamenal přesun politické moci z Vídně do Prahy, kultura či školství však zásadní transformací neprošly, protože již v českých rukách byly.

Situace Slovenska byla radikálně odlišná. Přežití národa bylo začátkem 20. století (při absenci vlastního školství, omezeném kulturním životě a vytrvalém mad’arizačním tlaku) akutní otázkou. Nebylo nemyslitelné, že Slováky postihne osud Lužických Srbů s jejich postupným splýváním s německou většinou. Vytvoření Československa a postavení státotvorného národa měly tedy pro Slováky přímo epochální význam. 28. říjnem 1918 vlastně ze dne na den získali historicky bezprecedentní 
politické postavení. Ještě důležitější byl rok 1918 pro Slováky v geografické rovině. Zatímco „české země“ byly odedávna relativně jasně definovaným historickým územím, Slovensko jako samostatný administrativní útvar nikdy předtím neexistovalo, jeho hranice se musely do velké míry nakreslit. Slovensko jako místo na mapě se tedy objevilo až vznikem ČSR.

Proč mají tedy Slováci ke vzniku Československa vlažnější vztah než Češi? Proč ta disparita? Odpověd’ je možné najít v rozdílném vnímání vztahu existence Československa k vlastnímu politickému sebeurčení a suverenitě u dvou národů. Historik Jan Rychlík ve své vynikající studii Češi a Slováci ve 20. století píše, že „, české společnosti panuje zásadní konsensus, že k saturování českých národních potřeb došlo v roce 1918 vznikem Československa, a to v plné mîre“. Proto je rok 1918 pro Čechy „mezníkem zcela zásadním“, kdy došlo k ,završení“ národního vývoje. ${ }^{1}$

Ve slovenské společnosti podobný konsensus nepanuje a nikdy nepanoval. Důvodem je neshoda v odpovědi na filosofickou otázku, v čem spočívá ono „saturování národních potřeb“. Možných je zde vícero odpovědí, v závislosti na zvolené definici důležitého pojmu ,sebeurčení národa“. David Miller, snad nejslavnější současný filosof věnující se nacionalismu, definuje sebeurčení jako ,institucionální strukturu, která jí [národní komunitě] umožňuje, aby kolektivně rozhodovala o věcech, které se primárně týkají této komunity“. ${ }^{2}$ Sám Miller hned v navazujících odstavcích vysvětluje, že tato definice je koncipována záměrně tak, aby z ní neplynula existence suverénního státu - přiznává však, že suverénní stát byl a je hlavním nástrojem, jak národního sebeurčení dosáhnout. Jiní teoretici tuto komplikaci nepřipouštějí. David Copp „právem na sebeurčení“ rozumí jednoduše ,právo získat, případně udržet si status státu“.3.

Pokud uznáme Slováky za samostatný národ s právem na sebeurčení (což je dnes nekontroverzní premisa), tak se jejich možná identifikace s ČSR okamžitě problematizuje. Svoji roli v tom hraje zejména 1) vědomí vlastní svébytnosti a kulturní odlišnosti a 2) postavení menšiny. Pokud tedy v českých zemích od začátku nebylo pochyb o tom, že Československo je vyvrcholením emancipačních snah českého národa, postoje

\footnotetext{
1 J. Rychlík, Češi a Slováci ve 20. století, Praha 2012, str. 11.

2 D. Miller, Citizenship and National Identity, Cambridge 2000, str. 27. Všechny citace z cizích jazyků v tomto textu jsou v mém vlastním překladu.

3 D. Copp, Democracy and Communal Self-Determination, in: J. McMahan R. Kim (vyd.), The Morality of Nationalism, Oxford 1997, str. 278.
} 
Slováků k Československu v letech 1918 až 1992 můžeme rozdělit na dva hlavní proudy. ${ }^{4}$ První z nich (,nacionalisté“) považovali Československo za další krok vývoje slovenského národa směrem k emancipaci, jejímž konečným výsledkem může být pouze vlastní stát. Podle této skupiny je nezávislost jedinou cestou k „saturování národních potřeb“ a národnímu sebeurčení, jak jej definuje David Copp. Druhá skupina („čechoslováci““) ${ }^{5}$ věřila, že plná nezávislost k saturování národních potřeb není nutná a že existence Československa netvoří překážku rozvoje slovenského národa. Naopak, může mu být (kulturně, ekonomicky, mezinárodně) prospěšná a Slováci ve společném státě můžou prosperovat bez toho, aby je tento stát omezoval. Tyto dvě skupiny jednoznačně kopírují výše citované filosofické postoje ohledně možností národního sebeurčení. Pokud nezávislost není nutná k sebeurčení a saturování národních potřeb, pak může být Československo trvalým politickým domovem slovenského národa - a to i v př́padě, že nezávislost Slovenska je geopoliticky možná. Pokud je však samostatný stát ultimátním vyvrcholením emancipačních snah každého národa, pak Československo může být jedině přechodným stádiem, v němž slovenský národ zůstává, dokud nenastanou vhodné podmínky pro jeho samostatnost.

Právě kvůli různému vztahu k národnímu sebeurčení byla situace v Československu od začátku silně asymetrická. Podpora československého státu, u české veřejnosti i elit přímočará, byla u Slováků vždy do jisté míry podmíněná. „Nacionalisté“ ho podporovali jenom za předpokladu, že plná nezávislost Slovenska není možná nebo vhodná. „Čechoslováci“" podporovali společný stát, protože je pro Slováky vhodným politickým domovem, přičemž saturuje jejich „národní potřeby“.

Rozdílný přístup ke společnému státu můžeme popsat také jako různé odpovědi na důležitou filosofickou otázku o fundamentální rovině legitimity politické moci. Toto je půda známé diskuse mezi kosmopolity a internacionalisty. První jmenovaní tvrdí, že státní moc, pokud má být legitimní, musí být ospravedlněna před lidstvem jako celkem, ${ }^{6}$ kdežto druzí trvají na tom, že zdrojem legitimity je souhlas obyvatelstva dané

\footnotetext{
$4 \quad$ Viz J. Rychlík, Češi a Slováci ve 20. století, str. 11-17.

5 Termínem ,čechoslováci“ budu označovat slovenské podporovatele společného státu. Se sílícím nacionalismem tento termín získal na počátku devadesátých let na Slovensku pejorativní význam, což však nebrání tomu, abych ho zde používal $\mathrm{v}$ jeho popisné funkci.

6 Viz např. A. Buchanan, Justice, Legitimacy, and Self-Determination. Moral Foundations for International Law, Oxford 2003.
} 
politické komunity. ${ }^{7}$ Internacionalismus (jenž nás vzhledem ke zvolenému tématu jako jediný zajímá) má však obtíže s převáděním svého postoje do praxe. Hranice žádné politické komunity totiž není možné apriorně určit. Zejména při mnohonárodních státech je situace mimořádně komplikovaná, protože není jasné, co tvoří „nejpůvodnějšǐ“ politickou komunitu, od níž se odvíjí legitimita politické moci na všech dalších úrovních. Tvoří ji veškeré obyvatelstvo daného státu? Nebo je mnohonárodní stát tvořen vícero politickými komunitami, jejichž souhlas je nutný k vytvoření legitimní společné vlády?

Právě tato nevyjasněnost sehrála v historii ČSR významnou úlohu. Československé orgány totiž představovaly pro Čechy (možná s výjimkou posledních měsíců existence ČSFR) základní úroveň politické legitimity, z níž se odvozovala a na níž závisela autorita dalších institucí (nižších orgánů v rámci federace, obecní samosprávy, ale i mezinárodních organizací). Vláda se tedy měla zodpovídat politické komunitě vymezené hranicemi Československa. Pro Slováky (z obou popsaných skupin) však byla tato „celostátní“ legitimita vždy alespoň z části derivativní. Slovensko tvořilo samostatnou politickou komunitu, na jejímž průběžném souhlase mělo záviset jakékoli další státoprávní uspořádání.

Problém asymetrie ve vnímání základní úrovně politické legitimity se ovšem netýká jen Československa. Will Kymlicka, významný kanadský filosof českého původu, jej např́klad popsal ve vztahu Kanady a Quebecu. ${ }^{8}$ I zde anglofonní kanadské obyvatelstvo vnímá jako základní celostátní politiku, od níž se odvozuje legitimita všech dalších orgánů politické moci. To je v prríkrém rozporu s frankofonními obyvateli Quebecu, kteří zdůrazňují své právo na sebeurčení (a to i v př́ípadě, že jsou proti samostatnosti). Souhlas obyvatel Quebecu, kteří jsou samostatným národem, je podle nich nutný k podepření legitimity kanadských úřadů na území této provincie.

Tato asymetrie ve vnímání základní úrovně politické legitimity ovšem přináší obtížné státoprávní otázky, které z povahy věci nejsou řešitelné právním kompromisem. Kymlicka např́íklad ukazuje, že kanadská federace (tedy politický systém založený na suverenitě sdílené centrální vládou a jednotlivými provinciemi) navzdory své funkčnosti nereprezentuje politické préedstavy svých obyvatel. Obyvatelé Quebecu ji „vnímají konfederativně“ - tedy tak, že svoji suverenitu (která jim přirozeně patří

\footnotetext{
7 Viz např. J. Rawls, The Law of Peoples, Cambridge 1999.

8 W. Kymlicka, Politics in the Vernacular. Nationalism, Multiculturalism, and Citizenship, Oxford 2001, str. 91-119.
} 
díky jejich právu na sebeurčení) pouze přepustili centrální vládě, a mohou si ji tedy kdykoli vzít zpět. ${ }^{9}$ Tento pocit však není sdílen anglofonními obyvateli, kteří na své provincie často nahlížejí pouze jako na decentralizované úrady státní správy a federaci chápou z hlediska politické legitimity a suverenity jako centralizovaný stát. Anglofonní obyvatelé Kanady proto vnímají celek tam, kde Quebečané vidí soustavu dvou původních částí. Jedná se o fundamentální problém politické percepce, jehož rozporuplnost se objevuje se železnou pravidelností vždy, když se otevře otázka kompetencí jednotlivých úrovní státní správy, případně když se zájmy státu a Quebecu začnou rozcházet. ${ }^{10}$

V Československu se problémy s asymetrickým vnímáním státu nejjasněji ukázaly v období mezi lety 1944-1948. Na Slovensku v té době působila Slovenská národná rada (SNR), která si svou legitimitu (a částečnou nezávislost na Benešově exilové vládě) těžce a za cenu velkých obětí vydobyla ve Slovenském národním povstání. Na podzim roku 1944 a na jaře roku 1945, v době, kdy Česko ještě bylo pod nacistickou okupací, proto osvobozené území ovládala slovenská autonomní vláda (tzv. ,zbor povereníkov“). Slovenští politici pak očekávali, že obdobné instituce zrcadlově vzniknou i v Česku, čímž se původně unitární ČSR decentralizuje podle národního klíče, v souladu s jejich představou o základní rovině legitimity politické moci. Tato očekávání však nebyla naplněna, protože centrální vláda začala řídit osvobozené území v Česku přímo. Čeští politici jednoduše neviděli důvod, proč vytvářet české autonomní orgány, pokud jejich funkci může efektivně zastat centrální vláda. Vznikl tak asymetrický model, jenž ovšem neměl dlouhého trvání. Částečné autonomii Slovenska učinil přítrž únor 1948 a následné čistky v KSČ, které ji důsledně zbavily všech „buržoazních nacionalistü“ (tedy slovenských komunistů prosazujících určitou úroveň autonomie). V ČSR zavládl Gottwaldův a pak Novotného tuhý centralismus. ${ }^{11}$

Ovšem samotná asymetrie ve vnímání základní úrovně politické legitimity nemusí být nutně zdrojem problémů a může najít své stabilní zakotvení. Dobrým příkladem je Velká Británie, kde existuje britská politická identita a současně s ní několik silných regionálních národních

9 Tamt., str. 113-115.

10 Nejostřeji vyjádřil představy obyvatel Quebecu jejich premiér Lucien Bouchard při svém inauguračním projevu v roce 1996: „Kanada je rozdělitelná, protože Kanada není skutečným státem. Je zde dvojí lid, dva národy a dvě území. A toto je to naše." Citováno podle M. Moore, The Ethics of Nationalism, Oxford 2001, str. 8.

11 J. Rychlík, Češi a Slováci ve 20. století, str. 283-288. 
identit, zejména u Skotů. Regionální politické identity však nemají svůj protějšek u většinového národa unie - Angličanů. Výše citovaný David Miller proto tvrdí, že Angličané vlastně nejsou politickým národem: „Můžeme pochybovat o tom, že existuje něco jako anglická národní identita... Vzhledem $\mathrm{k}$ tomu, jak se anglická a britská identita v hlavách Angličanů prolínají, neexistuje anglická národní identita, která vyžaduje politické uznání.“12

Tato pozice předpokládá rozlišení mezi kulturním a politickým národem. Angličané kulturním národem samozřejmě jsou, nicméně tento fakt se neprojevuje souborem politických požadavků mimo rámec „britské“ politiky. Jejich národní potřeby jsou plně saturovány existencí Velké Británie, v jejímž rámci jsou dominantní silou. Nemají proto zájem vytvářet separátní anglické politické struktury, podobně jako česká politická reprezentace neměla zájem vytvářet „české“ orgány v rámci Československa. To však nijak nebrání tomu, aby menšinové národy měly vlastní politickou reprezentaci a poměrně silnou autonomii. „Unijní“ parlament ve Westminsteru je proto doplněn skotským parlamentem v Holyroodu, který má široké pravomoci například v oblasti zdravotnictví, vzdělávání, spravedlnosti, ochrany životního prostředí, dopravy či ekonomického rozvoje. ${ }^{13}$

Zde se přirozeně nabízí otázka, zda Britové nepřišli na nejpřirozenější řešení problémů s asymetrií vnímání fundamentální úrovně politické legitimity. Ta se jednoduše může zrcadlit v asymetrickém institucionálním uspořádání, kdy Angličané volí své zástupce ve Westminsteru a Skotové jak ve Westminsteru, tak v Holyroodu. Vztah mezi parlamenty tedy reflektuje rozdíl mezi unitární politickou identitou na jedné straně a jejím rozdvojením na straně druhé.

Britské institucionální nastavení však v Československu nebylo uplatnitelné. Jedním z důvodů je situace poslanců autonomního celku v celostátní sněmovně. Při asymetrickém modelu totiž celostátní parlament schvaluje mnohé zákony, které platí jenom mimo autonomní území (v Británii napřr. ve zdravotnictví či školství). „Autonomní“ poslanci tak hlasují o právních úpravách, které na ,jejich“ území nebudou platit (anebo budou platit pouze omezeně), protože jsou v kompetenci místních úřadů. Tato situace v Británii přetrvává pouze proto, že Skoti obsazují jenom cca $9 \%$ z poslaneckých křesel ve Westminsteru (59 z 650), př́ičemž historicky byla vždy většina skotských poslanců členem hlavních

12 D. Miller, Citizenship and National Identity, str. 137. Kurziva v originálu.

13 Viz https://www.gov.uk/guidance/devolution-settlement-scotland. 
britských stran. Anglická veřejnost proto nemá pocit, že Skotové př́liš̌ mluví do jejich politiky, i když Angličané do skotské politiky mluvit nemohou. Politický systém proto může být více či méně stabilní. ${ }^{14}$

Situace, kdy by slovenští poslanci, tvořící zhruba třetinu parlamentu či vlády, spolurozhodovali o normách platících pouze či zejména na území Čech a Moravy, je však očividně politicky neudržitelná. To se ukázalo již v poválečném období „,zboru povereníkov“. Čeští politici tehdy poukazovali na fakt, že „ústřední vláda, ve které jsou i slovenští ministři, vládne fakticky jen v českých zemích, přičemž se ale na nařízeních pro české země slovenští ministři podílejí, zatímco na Slovensku, ačkoliv jsou ve vládě rovněž slovenští ministři, nevládne ústř̌ední vláda vůbec“" ${ }^{15}$ Lze proto říci, že asymetrický systém, i když by možná dobře reprezentoval politické percepce obyvatel Československa, u nás nemohl nikdy fungovat již z prostých aritmetických důvodů. Slovenský vliv na centrální vládu a parlament by $\mathrm{v}$ asymetrickém modelu byl vždy př́liš velký. Česká veřejnost by nemohla přehlédnout fakt, že Slováci regulují některé normy jak v Česku, tak na Slovensku, a Češi jenom v Česku. Britský model v Československu nebyl uplatnitelný.

Nejdůležitější problém soužití Čechů a Slováků se však netýkal otázky institucionální asymetrie ani problémů se základní úrovní legitimity politické moci. Klíčovými byly zejména otázky uznání a důstojnosti národa, jež je podle mnoha teoretiků nezbytné vzít v potaz, pokud máme pochopit fenomén nacionalismu jako takového. Charles Taylor ve své slavné knize Multiculturalism. Examining the Politics of Recognition ukazuje, že uznání a důstojnost jsou fundamentální kategorie identity moderního člověka, kolem nichž se točí velká část dnešních

14 Není náhoda, že k prvnímu omezení moci skotských poslanců došlo až v roce 2015, kdy Skotská národní strana (SNP) poprvé získala většinu skotských mandátů. Nová parlamentní pravidla („English votes for English laws“) proto vyžadují, aby návrh, který se týká pouze Anglie, mohl být schválen jenom tehdy, když pro něj hlasuje většina anglických poslanců. Nové pravidlo je však mimořádně problematické, a to zejména proto, že není možné jednoduše rozdělovat právní úpravy na dvě jasné kategorie (britské a pouze anglické). Moc anglických poslanců se tak nijak zásadně nezvýšila. Viz D. Gover - M. Kenny, Answering the West Lothian Question? A Critical Assessment of "English Votes for English Laws”, in: Parliamentary Affairs, 17. 2. 2018, https://doi.org/10.1093/pa/gsy003. I z těchto důvodů Will Kymlicka poukazuje na to, že nemáme žádný funkční systém, v němž by mohla být síla mandátu „,autonomních“ poslanců snížena alikvotně k tomu, kolik moci má jejich autonomní vláda. Takový systém v dějinách nikdy neexistoval. Viz W. Kymlicka, Politics in the Vernacular, str. 109.

15 J. Rychlík, Češi a Slováci ve 20. století, str. 285. 
společensko-politických diskusí (např́klad o feminismu, multikulturalismu či právech homosexuálů). ${ }^{16}$ Nejinak je tomu i s nacionalismem, který je odpovědí na veskrze moderní podmínky soužití lidských komunit. Ty jsou založené na individualismu a rovnosti, které nahradily těsnější komunitní vazby předmoderních společností. Výsledkem je, možná paradoxně, zvýšená citlivost na kolektivní identitu - která přímé komunitní vazby nevyžaduje -, a to zejména na identitu národní. ${ }^{17} \mathrm{Z}$ této zvýšené citlivosti pak plyne velký důraz na otázky rovných práv, diskriminace, dělení moci a, v první řadě, symbolického uznání.

Citlivost slovenských politiků k otázkám postavení či uznání slovenského národa byla ve společném státě přítomná vždy, když to politické podmínky dovolovaly. K jejímu vyhrocení však došlo především v krátkém období mezi sametovou revolucí a definitivním rozdělením dvou republik. Je přitom charakteristické, že neřešitelné rozpory Slováků a Čechů se primárně netýkaly těžkých politických otázek rozdělování kompetencí či společných financí. Ty byly samozřejmě předmětem náročných vyjednávání, jež však mohla skončit dohodou. Konsensus se podařilo najít u „kompetenčního zákona“ z roku $1990 .{ }^{18} \mathrm{I}$ v průběhu vyjednávání o podobě společného státu na podzim roku 1991 a na jaře roku 1992 panovala víceméně shoda na přerozdělení kompetencí mezi federální vládou na jedné straně a dvěma federálními republikami na straně druhé. ${ }^{19}$ Nepřekonatelné problémy nastávaly zejména v symbolické rovině. Je přitom symptomatické, že celý proces dělení zahájila zdánlivě nepodstatná ,pomlčková válka“, v níž šlo o to, zda název státu bude, nebo nebude obsahovat pomlčku (Československo vs. Česko-slovensko, případně Česko-Slovensko). Pro slovenské politiky však byla tato otázka stěžejní. Problém spočíval v tom, že „okolní svět ... chápal Československo jako stát český, přičemž adjektiva ,československý“ $\mathrm{a}$,český“ byla běžně v cizích jazycích zaměňována“. ${ }^{20}$ Klíčovým cílem slovenské politické reprezentace proto bylo „zviditelnění“ Slovenska, aby bylo každému jasné, že Slováci nejsou jenom svérázní Češi 1994.

16 C. Taylor, Multiculturalism. Examining the Politics of Recognition, Princeton

17 Týž, Nationalism and Modernity, in: J. McMahan - R. McKim (vyd.), The Morality of Nationalism, Oxford 1997.

18 Viz E. Stein, Česko-Slovensko. Konflikt, roztržka, rozpad, Praha 2000, str. $73-75$.

19 Tamt., str. 128-139.

20 J. Rychlík, Češi a Slováci ve 20. století, str. 552. 
z východu země. Důstojnost národa vyžadovala uznání, a to především uznání mezinárodní.

V krátkém období po sametové revoluci proto došlo k posunu politických priorit mezi dvěma národy. Slovy jednoho soudobého komentátora, „[Čechům] jde o co nejrychlejší návrat mezi vyspělé země, na Slovensku jde o národní sebepotvrzení“. ${ }^{21} \mathrm{Na}$ Slovensku jednoznačně platila teorie Charlese Taylora o fundamentální roli důstojnosti a uznání, přičemž ekonomické faktory, klíčové například v katalánském nacionalismu, „hrály pouze druhotnou roli““.22 Snaha o větší váhu a důstojnost národa se projevila i ve výběru politické reprezentace. Vladimír Mečiar dosáhl tak velkého úspěchu ve volbách, protože v něm část slovenských voličů spatřovala, slovy Petra Pitharta, „kompenzaci určitého svého komplexu méněcennosti ... viděla v něm sebedůvěru, která na Slovensku schází...“. „Mečiarův styl, který je nám [Čechům] tak cizí, jako razantnost ... je přesně to, co Slovensko chce v tuto chvíli vidět a slyšet.“"23

Byla to právě snaha o zviditelnění či uznání slovenského národa, která stála za rozpadem Československa. Slovenští politici v čele s Mečiarem totiž neměli s pokračováním společného státu problém. Zároveň však, v souladu s úsilím o ,zviditelnění“, vznášeli požadavky na mezinárodněprávní subjektivitu Slovenska, a zejména na „samostatné členství Slovenska v mezinárodních organizacích typu OSN“ či pozdější samostatný vstup do Evropského společenství. ${ }^{24}$ Tyto dvě pozice jsou samozřejmě v ostrém rozporu, protože např́íklad členství v OSN není jenom symbolickým vyjádřením svébytnosti národa, ale má zásadní mezinárodně-právní důsledky. Když však česká politická reprezentace vedená Václavem Klausem pozici Slováků dešifrovala jako úsilí o samostatnost a sama se za ni postavila, následovalo překvapení a (neúspěšná) snaha Mečiara rozpad zpomalit nebo zastavit. ${ }^{25}$ Lze proto říci, že úplná

21 E. Stein, Česko-Slovensko. Konflikt, roztržka, rozpad, str. 127.

22 Tamt., str. 231.

23 Tamt., str. 150, kurzíva v originálu. O vztahu určitého typu nacionalismu a nedostatku kolektivního sebevědomí píši obšírněji ve své knize M. Cíbik, Liberáli a tí druhí, Bratislava 2017, str. 107-109.

24 E. Stein, Česko-Slovensko. Konflikt, roztržka, rozpad, str. 161.

25 Ještě na podzim roku 1992 se v jednu chvíli zdálo, že Mečiar dokáže úspěšně vybudovat spojenectví s tehdejší českou opozicí a zabránit definitivnímu rozdělení ve prospěch volnějšího svazku Čechů a Slováků formou konfederace nebo unie. Tyto snahy však narazily na rezolutní Klausův odpor a nebyly úspěšné. Viz tamt., str. 179-185. 
samostatnost Slovenska a rozpad federace byly nechtěným důsledkem boje o uznání, jejž vedli slovenští politici.

Na závěr tohoto eseje bych si rád položil dvě spekulativní otázky. Byl rozpad společného státu nutný? A bylo možné problém vztahu Čechů a Slováků vyřešit $\mathrm{k}$ oboustranné trvalé spokojenosti? Jsem pevně přesvědčen, možná poněkud paradoxně, že odpověd’ zní dvakrát „ne“. Problém vztahu Čechů a Slováků nebylo možné vyřešit právě kvůli otevřené filosofické otázce, zda je samostatný stát nutným vyvrcholením politických aspirací každého národa. Slovenská veřejnost byla v této věci vždy rozpolcena a nebylo by realistické očekávat, že separatistické tendence dosažením jakéhokoli kompromisu vymizí. To však neznamená, že pokračování společného státu za těchto okolností není možné. Will Kymlicka při své analýze postavení Quebecu, Skotska či Katalánska konstatuje, že „úspěšné mnohonárodní federace často obsahují separatistická hnutí se značnou podporou. Aktivní a populární separatistická hnutí jsou každodenní a přijímanou součástí života demokratických mnohonárodních federací،“" ${ }^{26}$ Federace tedy mohla být životaschopná. Koneckonců idea Československa byla na Slovensku vždy populární - což je hlavní důvod, proč se nacionalistická SNS na počátku devadesátých let konzistentně stavěla proti myšlence referenda o samostatnosti Slovenska, a ani separatistická HSL'S na konci třicátých let neměla většinovou podporu. ${ }^{27}$ Československo proto mohlo fungovat stejně dobře jako jiné standardní demokratické mnohonárodní státy, které obsahují výše popsané konflikty a rozpory. To, že se rozpadlo, je navzdory zde popsaným problémům dílem kontingentní historie, a nikoli apriorní neslučitelnosti.

Matej Cíbik

26 W. Kymlicka, Politics in the Vernacular, str. 93.

27 J. Rychlík, Češi a Slováci ve 20. století, str. 144 a 584. 